\title{
A Systematic Analysis of the Alpine Saxifrage Complex (Saxifragaceae) in the Canadian Arctic Islands Using Morphology and Chloroplast DNA Data
}

\author{
Caroline Healy ${ }^{1}$ and Lynn J. Gillespie
}

Research Division, Canadian Museum of Nature, P.O. Box 3443, Station D, Ottawa, Ontario K1P 6P4, Canada

${ }^{1}$ Present address: Department of Biology, University of Ottawa, P.O. Box 450, Station A, Ottawa, Ontario K1N 6N5 Canada

Healy, Caroline, and Lynn J. Gillespie. 2004. A systematic analysis of the alpine saxifrage complex (Saxifragaceae) in the Canadian Arctic Islands using morphology and chloroplast DNA data. Canadian Field Naturalist 118(3): 326-340.

The Saxifraga nivalis complex displays significant ecological, morphological and cytological variation. Most European studies suggest that the $S$. nivalis complex comprises two distinct species: Saxifraga nivalis sensu stricto and Saxifraga tenuis. However, the presence of intermediate morphotypes, inconsistencies in chromosomal counts and variability in morphological keys and descriptions have led to different taxonomic interpretations of the complex in North America. This study investigated the systematics of Canadian Arctic Island members of this complex from 157 specimens using 23 morphological characters. Principal component analysis of the morphological data revealed two adjacent clusters, corresponding to the two taxa and consistent with a close morphological similarity and the presence of hybrids. A preliminary restriction site analysis of five non-coding regions of the chloroplast genome, $\operatorname{trn\mathrm {H}}-\operatorname{trn\mathrm {K}}, \operatorname{trn} \mathrm{T}-\operatorname{trn} \mathrm{F}, \operatorname{trn\mathrm {F}}-\operatorname{trn} \mathrm{V}, \operatorname{trn} \mathrm{V}-r b c \mathrm{~L}$ and $r b c \mathrm{~L}-\mathrm{ORF} 106$, was conducted using 21 restriction endonucleases. This analysis indicated a length difference between the $\operatorname{trnT}$ - $\operatorname{trn} \mathrm{F}$ region of $S$. nivalis and that of $S$. tenuis, but no difference in restriction sites for any of the assayed regions. These results confirm that in the Canadian Arctic, the S. nivalis complex consists of two closely related, largely sympatric species, with notable morphological variability, and possible hybrids.

Key Words: Alpine Saxifrage, Saxifraga nivalis, Saxifraga tenuis, Canadian Arctic, systematics, morphology, chloroplast DNA restriction site analysis.

Saxifraga L., the largest genus in the Saxifragaceae, consists of nearly 400 herbaceous, mostly perennial species (Webb 1993; Soltis et al. 1993, 1996). Saxifraga nivalis L. sensu lato, commonly known as the Alpine Saxifrage, inhabits arctic and alpine environments throughout the northern hemisphere. The $S$. nivalis complex is dispersed throughout northern and alpine Europe, Siberia, arctic and subarctic North America and south in the alpine zone to Arizona and the Gaspé, Quebec (Britton and Brown 1913; Krause and Beamish 1973; Scoggan 1978; Webb 1993). Members of the $S$. nivalis complex display notable morphological, cytological and ecological variation, which has led to different taxonomic interpretations and classifications.

Linnaeus (1753) first described S. nivalis, a name that means snow saxifrage, as these plants are often found growing in snow patch plant communities (Britton and Brown 1913). Later, Wahlenberg (1812) recognized $S$. nivalis var. tenuis Wahlenb. for plants with a notably smaller stature, fewer flowers, smaller fruits and recurved stigmas. Smith (in Lindman 1918) elevated Wahlenberg's variety to Saxifraga tenuis (Wahlenb.) Harry Sm. However, the taxonomy of the S. nivalis complex remained problematic and the acceptance of S. tenuis as a species was controversial. For instance, Böcher (1938) recognized S. nivalis and S. tenuis as distinct species, but also suspected the presence of races and microspecies within the $S$. nivalis complex. Polunin (1940) found the two taxa difficult to separate morpho- logically with intermediates and suggested the need for breeding and cytological studies before distinguishing them at the species level. Although accepted as a distinct species in Scandinavia and Greenland, based on samples from Alaska and the Yukon, Hultén (1945) concurred at the time with Polunin in treating the taxon as $S$. nivalis var. tenuis because of its minimal phenotypic distinction from $S$. nivalis and its low frequency of occurrence within the area of distribution of S. nivalis. However, in the Canadian Arctic, Porsild (1957, 1964) and Porsild and Cody (1980) recognized $S$. nivalis and S. tenuis as distinct species. Upon further examination of specimens from Alaska and neighboring regions, Hultén (1968) also recognized the two taxa at the species level. More recently Scoggan (1978) and Aiken et al. (1998) treat the two taxa as varieties of $S$. nivalis.

Taxonomic and nomenclatural ambiguity also stemmed from the description of additional varieties and microspecies, as well as the re-emergence of Haworth's (1812) suggestion to revise Linnaeus' concept of the genus Saxifraga (reviewed in Spongberg 1972). In 1905, Small divided the genus Saxifraga into 13 genera in North America (in Small and Rydberg 1905; reviewed in Soltis et al. 1996). Small treated S. nivalis as Micranthes nivalis (L.) Small, S. nivalis var. tenuis as Micranthes tenuis (Wahlenb.) Small, and distinguished an additional species in the Canadian eastern Arctic, Micranthes kumlienii Small. However, subsequent authors did not recognize the genus Micranthes, 
and $M$. kumlienii was treated as belonging to $S$. nivalis (Polunin 1940; Aiken et al. 2000*). Fernald (1917) distinguished Saxifraga nivalis var. labradorica Fern., a variety localized in Labrador, and suggested that this plant corresponded to Small's concept of Micranthes tenuis. Subsequently, this variety was treated as a synonym of S. nivalis var. tenuis (Scoggan 1978) or as a luxuriant form of the latter (Polunin 1940). In the Gaspé Peninsula, Fernald $(1917,1950)$ identified another member of the S. nivalis complex, Saxifraga gaspensis Fern. Subsequently, this species was included under S. nivalis var. tenuis (Scoggan 1950, 1978), treated as S. nivalis var. gaspensis (Fern.) Boivin (Boivin 1966), and then considered as small S. nivalis s.s. (Blondeau 1989a). Most recently, Gervais et al. (1995) followed Fernald in treating the Gaspé population as a distinct species. In Alaska, Hultén (1968) considered S. nivalis as highly variable, recognizing $S$. nivalis var. tenuis, and describing S. nivalis var. rufopilosa Hultén for plants characterized by "densely pubescent, rufoushaired leaves and red petals" (page 579) found in Alaska and the Yukon. Porsild (1957, map page 188) appeared to treat $S$. rufopilosa under S. tenuis according to his map of that species (see also Porsild and Cody 1980, map page 403; Cody 1996). Later, Porsild (1975) recognized the latter as the distinct species, $S$. rufopilosa (Hult.) A. E. Porsild, and suggested that it was more closely related to $S$. tenuis than $S$. nivalis. Cody (1996) also recognized $S$. rufopilosa as a distinct species and considered $S$. tenuis as not present in the Yukon. In 1978, Scoggan's concept of S. nivalis var. tenuis encompassed S. tenuis, S. gaspensis, S. nivalis var. labradorica and $S$. nivalis var. rufopilosa.

Based on cytology and morphology, Löve (1983) and Webb $(1964,1993)$ discerned the species $S$. nivalis $(2 \mathrm{n}=60)$ and S. tenuis $(2 \mathrm{n}=20)$ in Europe. The taxonomic ambiguity regarding the $S$. nivalis complex in North America (Aiken et al. 2000*) appears to stem from the following factors: (1) several morphological characters used to distinguish the species in Europe do not hold up in North America; (2) taxa can be found growing together; and (3) intermediate morphotypes, as well as variation in chromosomal counts suggest hybridization. Various cytological studies of material from North America have demonstrated cytological diversity within the $S$. nivalis complex with chromosomal counts of $2 \mathrm{n}=20,40$, c. $56,58,60$ or c. 60 . While most support the above European counts for $S$. nivalis and S. tenuis (Mosquin and Hayley 1966; Hedberg 1967; Johnson and Packer 1968; Packer and McPherson 1974; Löve and Löve 1975), several studies found intermediate chromosome counts. Krause and Beamish (1973) provide counts for plants of the $S$. nivalis-tenuis complex from the Yukon $(2 \mathrm{n}=20,40)$, British Columbia (60) and Idaho (20), which they were unable to identify to species. Intermediate chromosome counts have also been found in the Russian Arctic in a plant described as $S$. nivalis $\times$ S. tenuis (Devyatov et al. 1997). In the Gaspé Peninsula S. gaspensis is considered to be a putative endemic hybrid based on chromosome number $(2 n=40)$ and apparent intermediate morphology (Gervais et al. 1995). Further confusion results from the variance and discrepancies among the morphological keys used in the identification of this complex and related species, such as $S$. foliolosa R. Br., which are occasionally misidentified as members of the S. nivalis complex. Consequently, accurate and consistent identification of North American plants belonging to this complex can be problematic.

The aim of this study was to investigate the distinctiveness of $S$. nivalis and $S$. tenuis in the Canadian Arctic Islands based on morphological and molecular differences, and to help reassess the taxonomic status of S. tenuis.

\section{Material and Methods Morphological Analysis Specimens}

Representative specimens from the Canadian Arctic were selected from the Canadian National Herbarium, Canadian Museum of Nature (CAN), and the Agriculture and Agri-foods Canada Herbarium, Central Experimental Farm, Ottawa (DAO). Morphological data were gathered from observations and measurements on 157 herbarium sheets (listed in Appendix I), including two chromosome count vouchers ( $S$. nivalis, $2 \mathrm{n}=60$, Calder et al. DAO 24148; S. tenuis, $2 \mathrm{n}=20$, Calder et al. DAO 24149). One plant per sheet was sampled, except when sheets comprised mixed collections or included DNA vouchers, and then multiple plants per sheet were sampled. A total of 200 plants were sampled, 122 S. nivalis and $78 \mathrm{~S}$. tenuis. More specimens of $S$. nivalis were available for study than of S. tenuis. Where identifications of examined specimens were judged questionable, specimens were re-identified based on a combination of published keys and preliminary results. Additionally, identifications of many $S$. tenuis specimens at CAN were subsequently confirmed for the Panarctic Flora Project (E. Reidar, 2001, 2002).

\section{Morphological characters}

Characters used in descriptions and keys of the $S$. nivalis complex (Simmons 1906; Polunin 1940; Porsild 1957; Löve 1983; Blondeau 1989a, 1989b; Webb 1993; Aiken et al. 1998, 2000*) were reduced to a set of 30 characters based on ease of observation or measurement on dried specimens as well as their taxonomic significance. Of these, 23 were selected for statistical analysis (Table 1). Petal length was excluded from all analyses due to difficulties in measuring petals that were often folded and partly included within the calyx. The qualitative characters, stem colour, petal shape, prominence of leafy bract on stem, leaf blade shape, leaf blade base shape and apex shape, were excluded due to variation within a plant or difficulties in determining discrete states. 
TABLE 1. Morphological characters used in analyses of the Saxifraga nivalis complex in the Canadian Arctic.
Quantitative characters:
1. Plant height $(\mathrm{cm})$ : HEIGHT; length from basal rosette to top of inflorescence
2. Stem width (mm): STWIDTH; measured midway along lower half of stem
3. Stem hair density (0, glabrous to 4, dense): STHRDENSITY
4. Stem hair length (mm): STHRLENGTH; measured midway along lower half of stem.
5. Leaf blade length (cm): LFLENGTH; measurement made on the largest leaf
6. Leaf blade width (cm): LFWIDTH; measurement made on the largest leaf
7. Hair length on leaf lower surface (mm): UNDHRLGTH
8. Hair length along leaf margin ( $\mathrm{mm})$ : MRGHRLGTH
9. Number of teeth on leaf: TEETH; count made on the largest leaf
10. Tooth width (mm): TTHWIDTH; measurement made on largest tooth on the largest leaf
11. Tooth length $(\mathrm{mm})$ : TTHLENGTH; measurement made on largest tooth on the largest leaf
12. Petal width (mm): PTWIDTH; measurement made on the largest petal

Qualitative characters:

1. Stem hair colour (rust-coloured; mixed rust and white; white)

2. Stem hair texture (short fine; long coarse)

3. Tooth apex shape (rounded; pointed)

4. Regularity of teeth (even in size; variable in size smaller towards leaf blade apex)

5. Hair presence on leaf lower surface (moderate to dense; sparse; absent)

6. Hair colour on leaf lower surface (rust; white)

7. Hair presence on leaf margin (moderate to dense; sparse; absent)

8. Hair colour on leaf margin (rust; white)

9. Inflorescence density (open; tight cluster)

10. Style shape (curved; straight or essentially so)

11. Petal colour (pink or essentially so; white or essentially so)

The software package DELTA (Dallwitz et al. 1993) and the character set for the "Flora of the Canadian Arctic Archipelago" (Aiken et al. 2002*) were used to generate preliminary taxon descriptions. These descriptions were then modified to read more easily, to exclude irrelevant characters, and to include important diagnostic characters not included in the Flora character set.

\section{Statistical analysis}

All statistical analyses were performed with SYSTAT version 8.0. For each quantitative trait, the means for $S$. tenuis and S. nivalis specimens were compared by performing t-tests. Separate variance values were calculated for each taxon. T-tests were conducted on both raw and log-transformed data. A principal component analysis (PCA) using the 12 quantitative characters indicated in Table 1 was conducted to visualize possible distinctiveness between $S$. nivalis and $S$. tenuis. The character MRGHLGTH was excluded from some PCA analyses due to a large amount of missing data in $S$. tenuis, which sometimes lacked marginal hairs. The PCA analysis excluded all specimens with missing values. A discriminant function analysis was also performed on the quantitative data. For the 11 selected qualitative characters (Table 1) the percentages of specimens having each character state was determined for each taxon.

To determine if there was any geographical pattern to the morphological variation in $S$. tenuis, principal component analysis was performed only on the $S$. tenuis quantitative data (excluding MRGHLGTH). This analysis also included five specimens from Alas- ka (Calder 6107, 6511, 6249 DAO) and northern British Colombia (Calder \& Kukkonen 28151 DAO, Taylor et al. 1204 DAO) not included in the larger analysis. Individuals were coded as occurring in one of three regions: high arctic (67), eastern arctic (11) or western montane (5).

\section{Chloroplast DNA analysis \\ Plant material and DNA extraction}

A total of 15 plants, for which silica gel dried material was available, were selected for molecular analysis: seven individuals of S. nivalis (Gillespie 6165, 6675-1, 6826a-1, 6826a-2, 6977-2, 6984-5; Aiken 98-055-3), seven S. tenuis (Gillespie 6728-1, 6807-1, 6807-3, 6825-2, 6870-2, 6877-1, 6881-3), and one S. foliolosa (Gillespie 6841) (Appendix 1). The latter species was selected to provide perspective on the chloroplast DNA (cpDNA) data, based on its close phylogenetic relationship to the $S$. nivalis complex (Soltis et al. 1996). DNA was extracted following Doyle and Doyle's (1990) CTAB total DNA extraction procedure as modified by Gillespie et al. (1997).

\section{Restriction site analysis}

DNA extracts were PCR amplified using five pairs of universal primers for non-coding regions of chloroplast DNA. The five regions are: $\operatorname{trn} \mathrm{H}-\operatorname{trnK}$ (Demesure et al. 1995), $t r n \mathrm{~T}-\operatorname{trn} \mathrm{F}$ (Taberlet et al. 1991), $t r n \mathrm{~F}-\operatorname{trn} \mathrm{V}$ (Dumoulin-Lapegue et al. 1997), trnV-rbcL (Dumoulin-Lapegue et al. 1997), and rbcL-ORF106 (Arnold et al. 1991). Amplification reaction mix and programs follow Gillespie and Boles (2001). 
TABle 2. Descriptive statistics and t-test comparing the means of S. nivalis and S. tenuis at the $95 \%$ confidence level for 12 quantitative morphological characters.

\begin{tabular}{|c|c|c|c|c|c|c|c|c|c|}
\hline \multirow[b]{2}{*}{ Character } & \multirow[b]{2}{*}{ Taxon } & \multirow[b]{2}{*}{$\mathrm{N}$} & \multirow[b]{2}{*}{ Mean $( \pm S D)$} & \multicolumn{2}{|c|}{ Range } & \multirow{2}{*}{$\begin{array}{c}\text { Difference } \\
\text { in means }\end{array}$} & \multirow[b]{2}{*}{$\mathrm{t}$ value } & \multirow[b]{2}{*}{ df } & \multirow[b]{2}{*}{$\mathrm{p}$} \\
\hline & & & & Min & Max & & & & \\
\hline \multirow{4}{*}{ Plant height $(\mathrm{cm})$} & S. nivalis & 122 & $9.12( \pm 3.37)$ & 1.7 & 18.0 & \multirow{3}{*}{4.66} & \multirow{3}{*}{13.68} & \multirow{3}{*}{176.2} & \multirow{3}{*}{0.000} \\
\hline & & & & & & & & & \\
\hline & S. tenuis & 78 & $4.40( \pm 1.40)$ & 1.8 & 8.5 & & & & \\
\hline & S. nivalis & 122 & $1.37( \pm 0.35)$ & 0.7 & 2.5 & \multirow{3}{*}{0.82} & \multirow{3}{*}{23.06} & \multirow{3}{*}{178.6} & \multirow{3}{*}{0.000} \\
\hline \multirow[t]{2}{*}{ Stem width $(\mathrm{mm})$} & & & & & & & & & \\
\hline & S. tenuis & 78 & $0.56( \pm 0.15)$ & 0.3 & 1.0 & & & & \\
\hline \multirow{3}{*}{ Stem hair density } & S. nivalis & 122 & $3.2( \pm 0.70)$ & 1 & 4 & \multirow{3}{*}{2.0} & \multirow{3}{*}{24.94} & \multirow{3}{*}{205.0} & \multirow{3}{*}{0.000} \\
\hline & & & & & & & & & \\
\hline & S. tenuis & 78 & $1.2( \pm 0.36)$ & 1 & 3 & & & & \\
\hline \multirow{3}{*}{ Stem hair length $(\mathrm{mm})$} & S. nivalis & 122 & $3.2( \pm 0.70)$ & 1 & 4 & \multirow{3}{*}{0.67} & & & \\
\hline & & & & & & & 35.45 & 188.5 & 0.000 \\
\hline & S. tenuis & 77 & $0.19( \pm 0.09)$ & 0.1 & 0.5 & & & & \\
\hline & S. nivalis & 119 & $0.96( \pm 0.34)$ & 0.4 & 2.1 & & & & \\
\hline Leaf blade width $(\mathrm{cm})$ & & & & & & 0.51 & 14.81 & 161.2 & 0.000 \\
\hline & S. tenuis & 77 & $0.44( \pm 0.13)$ & 0.2 & 0.8 & & & & \\
\hline & S. nivalis & 119 & $1.38( \pm 0.50)$ & 0.6 & 3.6 & & & & \\
\hline Leaf blade length $(\mathrm{cm})$ & & & & & & 0.69 & 13.51 & 166.5 & 0.000 \\
\hline & S. tenuis & 77 & $0.67( \pm 0.18)$ & 0.4 & 1.5 & & & & \\
\hline Hair length on lower & S. nivalis & 120 & $0.38( \pm 0.13)$ & 0.2 & 1.2 & & & & \\
\hline leaf surface $(\mathrm{mm})$ & & & & & & 0.10 & 7.25 & 197.0 & 0.000 \\
\hline & S. tenuis & 78 & $0.27( \pm 0.06)$ & 0.1 & 0.5 & & & & \\
\hline Hair length on & S. nivalis & 121 & $0.19( \pm 0.07)$ & 0.1 & 0.4 & & & & \\
\hline leaf margin $(\mathrm{mm})$ & S. tenuis & $55^{*}$ & $0.12( \pm 0.04)$ & 0.1 & 0.2 & 0.07 & 8.47 & 167.4 & 0.000 \\
\hline Number of teeth & S. nivalis & 118 & $10.3( \pm 1.74)$ & 7 & 14 & & & & \\
\hline on leaf blade & & & & & & 2.8 & 16.63 & 167.8 & 0.000 \\
\hline & S. tenuis & 78 & $7.5( \pm 0.73)$ & 6 & 9 & & & & \\
\hline & S. nivalis & 118 & $1.17( \pm 0.42)$ & 0.5 & 3.5 & & & & \\
\hline Tooth width (mm) & & & & & & 0.37 & 7.86 & 195.6 & 0.000 \\
\hline & S. tenuis & 78 & $0.80( \pm 0.24)$ & 0.5 & 1.6 & & & & \\
\hline & S. nivalis & 118 & $1.52( \pm 0.48)$ & 0.8 & 3.2 & & & & \\
\hline Tooth length (mm) & & & & & & 0.62 & 11.84 & 190.5 & 0.000 \\
\hline & S. tenuis & 78 & $0.90( \pm 0.26)$ & 0.4 & 1.8 & & & & \\
\hline & S. nivalis & 120 & $1.12( \pm 0.24)$ & 0.7 & 1.8 & & & & \\
\hline Petal width (mm) & & & & & & 0.40 & 14.16 & 202.0 & 0.000 \\
\hline & S. tenuis & 77 & $0.72( \pm 0.16)$ & 0.5 & 1.1 & & & & \\
\hline
\end{tabular}

* Marginal hair was not present in all S. tenuis

PCR products were single digested with twenty one restriction endonucleases according to manufacturer's recommendations. These included nine 4-base pair (bp) cutting restriction enzymes: AluI, HaeIII, HhaI, MspI, RsaI, DdeI, HinfI, Sau96I, TaqI; two 5bp cutting restriction enzymes: $B s t \mathrm{OI}, \operatorname{Sin} \mathrm{I}$; and ten 6bp enzymes:
ApaI, BamHI, BglI, BglII, DraI, EcoRI, EcoRV, HincII, $P s t \mathrm{I}, \mathrm{XhoI}$. To separate restriction fragments, $8 \mu \mathrm{L}$ of the reaction mixture and $2 \mu \mathrm{L}$ of buffer-dye mix were run on $1.1 \%$ agarose gels with ethidium bromide at $38 \mathrm{~V}$ for $2-3 \mathrm{hrs}$. The restriction fragment patterns were visualized and photographed under ultraviolet light. 
TABle 3. Distribution of qualitative morphological character states in Saxifraga nivalis and S. tenuis in the Canadian Arctic. Numbers represent percentage of individuals having a particular character state.

\begin{tabular}{|c|c|c|c|}
\hline Character & Character state & S. nivalis & S. tenuis \\
\hline \multirow[t]{3}{*}{ Stem hair colour } & rust & 1.3 & 74.4 \\
\hline & mixed & 0 & 25.6 \\
\hline & white & 98.7 & 0 \\
\hline \multirow[t]{2}{*}{ Stem hair texture } & short fine & 1.6 & 100 \\
\hline & long coarse & 98.4 & 0 \\
\hline \multirow[t]{2}{*}{ Tooth apex shape } & rounded & 2.5 & 100 \\
\hline & pointed & 97.5 & 0 \\
\hline \multirow[t]{2}{*}{ Regularity of teeth } & even-sized & 18.3 & 87.2 \\
\hline & variable & 81.7 & 12.8 \\
\hline \multirow[t]{3}{*}{ Hairs presence on leaf lower surface } & moderate-dense & 91.7 & 84.6 \\
\hline & sparse & 7.5 & 15.4 \\
\hline & absent & 0.8 & 0 \\
\hline \multirow[t]{2}{*}{ Hair colour on leaf lower surface } & rust & 40.0 & 79.5 \\
\hline & white & 60.0 & 20.5 \\
\hline \multirow[t]{3}{*}{ Hair presence on leaf margin } & moderate-dense & 91.7 & 10.3 \\
\hline & sparse & 8.3 & 60.3 \\
\hline & absent & 0 & 29.5 \\
\hline \multirow[t]{2}{*}{ Hair colour on leaf margin } & rust & 20.7 & 60.0 \\
\hline & white & 79.3 & 40.0 \\
\hline \multirow[t]{2}{*}{ Inflorescence density } & open & 1.8 & 97.1 \\
\hline & tight cluster & 98.2 & 2.9 \\
\hline \multirow[t]{2}{*}{ Style shape } & curved & 25.9 & 84.7 \\
\hline & straight & 74.1 & 15.3 \\
\hline \multirow[t]{2}{*}{ Petal colour } & pink & 14.9 & 81.8 \\
\hline & white & 85.1 & 18.2 \\
\hline
\end{tabular}

Lengths of total amplified product and restriction fragments were estimated by comparison with known 100 bp ladder DNA markers.

\section{Results \\ Morphological Analysis}

To determine whether the means of the examined quantitative characters were different between $S$. nivalis and $S$. tenuis, t-tests were performed (Table 2). The analysis revealed a significant difference in means between the two taxa for all characters examined. Overall, plants belonging to $S$. nivalis are more robust than $S$. tenuis as implied by higher means in both plant height and stem width observed in S. nivalis. Similarly, leaves of $S$. nivalis are on average longer, wider and have longer, wider and more numerous marginal teeth than S. tenuis. Also, hairs on the stems are longer and denser and hairs on the lower surface and margin of leaves are on average longer in $S$. nivalis. Petal width was significantly greater in $S$. nivalis than in S. tenuis. However, the two taxa have notably different variances, with $S$. nivalis having a higher variance than $S$. tenuis for all quantitative characters examined. Considering the very low probability values and the robustness of t-tests for samples of this size, the differences in means can be considered as meaningful. Analyses were also performed on log-transformed data, with no significant differences.

The frequency of occurrence of states of qualitative characters differed considerably between the two taxa for most characters (Table 3). The characters, stem hair colour and texture, tooth apex shape and inflorescence density, differed significantly between the two taxa, with less than a five percent overlap in states. Several characters, regularity of teeth, petal colour and style shape, exhibited an overlap in states of $10-26 \%$ between the two taxa. In contrast, one character, hair presence on lower leaf surface, displayed very similar frequencies of states between $S$. nivalis and $S$. tenuis, with hairs present in over $95 \%$ of the specimens examined in both taxa, although density was sometimes more sparse in $S$. tenuis. The remaining characters displayed considerable overlap in states between the taxa.

The principal component analysis of quantitative characters (excluding MRGHLGTH) revealed two clusters, positioned adjacent to each other with little overlap (Figure 1). Factor loading for the analysis was STWIDTH, LFWIDTH, LFLENGTH, STHRLENGTH, STHRDENSITY, HEIGHT, TEETH, PTWIDTH and TTHLENGTH for factor 1, and TTHWIDTH and UNDHRLGTH for factor 2 , with $61 \%$ and $10 \%$ of total variance explained by factors 1 and 2, respectively. As noted above, there is considerable variation among $S$. nivalis plants for most examined characters. This can be observed on the graph through the large oblique spread of $S$. nivalis compared to $S$. tenuis. The PCA including the character MRGHLGTH produced very similar results (although displayed fewer individuals). The discriminant function analysis performed on the same data distinguished between the two taxa $100 \%$ 


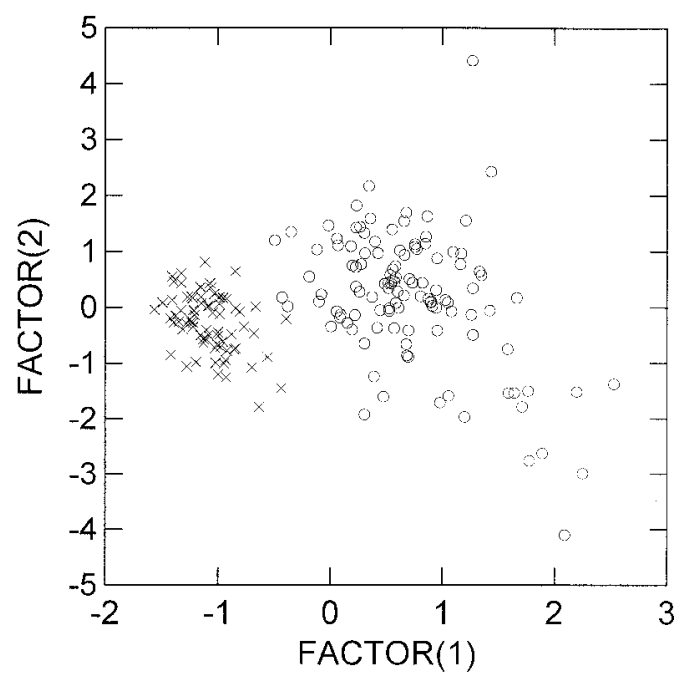

Figure 1. Principal component analysis on the quantitative morphological data set for the Saxifraga nivalis complex in the Canadian Arctic. Circles represent individuals of S. nivalis, crosses represent S. tenuis.

of the time, with one dimension accounting for the variation.

The PCA analysis examining geographical patterns to morphological variation in S. tenuis revealed very little geographical structure, with eastern arctic and high arctic plants almost completely overlapping.
Western montane plants separated from the majority of arctic plants on a combination of both factors (with LFWIDTH, LFLENGTH, and TEETH, loading high on factor one, HEIGHT on factor two), but overlapped considerably with several eastern arctic plants. A discriminant function analysis performed on the three geographic groups produced similar results (correctly placing the western montane plants with $100 \%$ reliability, high arctic plants with $86 \%$ reliability, and eastern arctic plants with only $42 \%$ reliability).

\section{Chloroplast DNA analysis}

The $t r n \mathrm{H}-\operatorname{trn\mathrm {K}}$ amplicons were estimated at 1600 base pairs (bp) for S. nivalis and S. tenuis and $1700 \mathrm{bp}$ for $S$. foliolosa. The three largest regions, $\operatorname{trn} \mathrm{F}-\operatorname{trn} \mathrm{V}$, $t r n \mathrm{~V}-r b c \mathrm{~L}$ and $r b c \mathrm{~L}-\mathrm{ORF} 106$, were approximately 3000 bp in length in all three taxa. Interestingly, the trnT-trnF region was estimated to be $1800 \mathrm{bp}, 1850 \mathrm{bp}$ and 2000 bp in length for S. nivalis, S. tenuis and $S$. foliolosa, respectively.

Sixteen out of 105 enzyme restriction assays showed restriction site differences between $S$. foliolosa and the $S$. nivalis complex, including three site differences in the $t r n \mathrm{H}-t r n \mathrm{~K}$ region, three in the $r b c \mathrm{~L}-\mathrm{ORF} 106$ region, three in the $t r n \mathrm{~V}-r b c \mathrm{~L}$ region, five in the $t r n \mathrm{~F}-$ $t r n \mathrm{~V}$ region and two in the $\operatorname{trn} \mathrm{T}-t r n \mathrm{~F}$ region (Table 4). No restriction site differences were detected between $S$. nivalis and $S$. tenuis. However, digestion of the $t r n \mathrm{~T}-t r n \mathrm{~F}$ region with the restriction enzyme $A l u \mathrm{I}$ showed clearly the length difference between $S$. nivalis and S. tenuis (Figure 2).

Table 4. Data matrix of restriction site characters for S. nivalis (N), S. tenuis $(\mathrm{T})$ and S. foliolosa (F). "0" represents absence of restriction site; "1" represents presence of restriction site.

\begin{tabular}{|c|c|c|c|c|c|}
\hline & $\begin{array}{c}\operatorname{trn} \mathbf{H}-\boldsymbol{t} \boldsymbol{t} \boldsymbol{n} \mathbf{K} \\
\mathrm{N} \mathrm{T} \mathrm{F} \\
\end{array}$ & $\begin{array}{c}r b c L-O R F 106 \\
\text { N T F }\end{array}$ & $\begin{array}{c}\boldsymbol{t r n} \mathbf{V} \text {-rbcL } \\
\mathrm{N} \mathrm{T} \mathrm{F} \\
\end{array}$ & $\begin{array}{c}\operatorname{trn} \mathbf{F}-\operatorname{trn} V \\
\mathrm{~N} \mathrm{~T} \mathrm{~F} \\
\end{array}$ & $\begin{array}{c}\boldsymbol{t r n} \text { T-trnF } \\
\text { N T F }\end{array}$ \\
\hline$A l u \mathrm{I}$ & $\begin{array}{lll}11 & 1\end{array}$ & $\begin{array}{lll}1 & 1 & 1\end{array}$ & $\begin{array}{lll}1 & 1 & 1\end{array}$ & $\begin{array}{lll}1 & 1 & 1\end{array}$ & $\begin{array}{lll}1 & 1 & 1\end{array}$ \\
\hline Apa I & $\begin{array}{lll}0 & 0 & 0\end{array}$ & $\begin{array}{lll}0 & 0 & 0\end{array}$ & $\begin{array}{lll}0 & 0 & 0\end{array}$ & $\begin{array}{lll}0 & 0 & 0\end{array}$ & $\begin{array}{lll}0 & 0 & 0\end{array}$ \\
\hline BamH I & $\begin{array}{lll}0 & 0 & 0\end{array}$ & $\begin{array}{lll}1 & 1 & 1\end{array}$ & $\begin{array}{lll}0 & 0 & 1\end{array}$ & $\begin{array}{lll}0 & 0 & 0\end{array}$ & $\begin{array}{lll}0 & 0 & 0\end{array}$ \\
\hline$B g l \mathrm{I}$ & $\begin{array}{lll}0 & 0 & 0\end{array}$ & $\begin{array}{lll}0 & 0 & 0\end{array}$ & $\begin{array}{lll}0 & 0 & 0\end{array}$ & $\begin{array}{lll}0 & 0 & 0\end{array}$ & $\begin{array}{lll}0 & 0 & 0\end{array}$ \\
\hline$B g l$ II & $\begin{array}{lll}0 & 0 & 0\end{array}$ & $\begin{array}{lll}1 & 1 & 1\end{array}$ & $\begin{array}{lll}0 & 0 & 0\end{array}$ & 110 & $\begin{array}{lll}0 & 0 & 0\end{array}$ \\
\hline BstO I & $\begin{array}{lll}0 & 0 & 1\end{array}$ & 111 & $\begin{array}{lll}0 & 0 & 1\end{array}$ & $\begin{array}{lll}0 & 0 & 0\end{array}$ & 111 \\
\hline Dra I & $\begin{array}{lll}0 & 0 & 1\end{array}$ & 110 & $\begin{array}{lll}0 & 0 & 1\end{array}$ & $\begin{array}{lll}0 & 0 & 0\end{array}$ & $\begin{array}{lll}0 & 0 & 1\end{array}$ \\
\hline EcoR I & $\begin{array}{lll}0 & 0 & 0\end{array}$ & $\begin{array}{lll}11 & 1\end{array}$ & $\begin{array}{lll}0 & 0 & 0\end{array}$ & $\begin{array}{lll}0 & 0 & 1\end{array}$ & $\begin{array}{lll}0 & 0 & 1\end{array}$ \\
\hline EcoR V & $\begin{array}{lll}0 & 0 & 0\end{array}$ & 111 & $\begin{array}{lll}0 & 0 & 0\end{array}$ & $\begin{array}{lll}0 & 0 & 0\end{array}$ & $\begin{array}{lll}0 & 0 & 0\end{array}$ \\
\hline Hae III & $\begin{array}{lll}1 & 1 & 1\end{array}$ & $\begin{array}{lll}0 & 0 & 1\end{array}$ & $\begin{array}{lll}1 & 1 & 1\end{array}$ & $\begin{array}{lll}0 & 0 & 1\end{array}$ & $\begin{array}{lll}0 & 0 & 0\end{array}$ \\
\hline Hha I & $\begin{array}{lll}0 & 0 & 0\end{array}$ & $\begin{array}{lll}0 & 0 & 0\end{array}$ & $\begin{array}{lll}11 & 1\end{array}$ & $\begin{array}{lll}0 & 0 & 0\end{array}$ & $\begin{array}{lll}0 & 0 & 0\end{array}$ \\
\hline $\operatorname{Hinf} \mathrm{I}$ & 111 & $\begin{array}{lll}11 & 1\end{array}$ & $\begin{array}{lll}11 & 1\end{array}$ & 111 & $\begin{array}{lll}0 & 0 & 0\end{array}$ \\
\hline$M s p$ I & $\begin{array}{lll}1 & 1 & 1\end{array}$ & 111 & $\begin{array}{lll}1 & 1 & 1\end{array}$ & 111 & $\begin{array}{lll}0 & 0 & 0\end{array}$ \\
\hline$N c i \mathrm{I}$ & 110 & 111 & $\begin{array}{lll}11 & 1\end{array}$ & 111 & $\begin{array}{lll}11 & 1\end{array}$ \\
\hline Pst I & $\begin{array}{lll}11 & 1\end{array}$ & $\begin{array}{lll}11 & 1\end{array}$ & $\begin{array}{lll}0 & 0 & 0\end{array}$ & $\begin{array}{lll}0 & 0 & 0\end{array}$ & $\begin{array}{lll}0 & 0 & 0\end{array}$ \\
\hline$P v u$ II & $\begin{array}{lll}0 & 0 & 0\end{array}$ & $\begin{array}{lll}0 & 0 & 0\end{array}$ & $\begin{array}{lll}1 & 1 & 1\end{array}$ & 110 & $\begin{array}{lll}0 & 0 & 0\end{array}$ \\
\hline$R s a \mathrm{I}$ & $\begin{array}{lll}0 & 0 & 0\end{array}$ & 111 & $\begin{array}{lll}1 & 1 & 1\end{array}$ & $\begin{array}{lll}1 & 1 & 1\end{array}$ & $\begin{array}{lll}0 & 0 & 0\end{array}$ \\
\hline Sau96 I & 111 & 111 & $\begin{array}{lll}1 & 1 & 1\end{array}$ & $\begin{array}{lll}1 & 1 & 1\end{array}$ & $\begin{array}{lll}1 & 1 & 1\end{array}$ \\
\hline Sin I & 111 & 111 & 111 & $\begin{array}{lll}11 & 1\end{array}$ & $\begin{array}{lll}0 & 0 & 0\end{array}$ \\
\hline Taq I & $\begin{array}{lll}0 & 0 & 0\end{array}$ & $\begin{array}{lll}0 & 0 & 1\end{array}$ & $\begin{array}{lll}1 & 1 & 1\end{array}$ & $\begin{array}{lll}1 & 1 & 1\end{array}$ & $\begin{array}{lll}1 & 1 & 1\end{array}$ \\
\hline Xho I & $\begin{array}{lll}0 & 0 & 0\end{array}$ & $\begin{array}{lll}0 & 0 & 0\end{array}$ & $\begin{array}{lll}0 & 0 & 0\end{array}$ & 110 & $\begin{array}{lll}0 & 0 & 0\end{array}$ \\
\hline
\end{tabular}




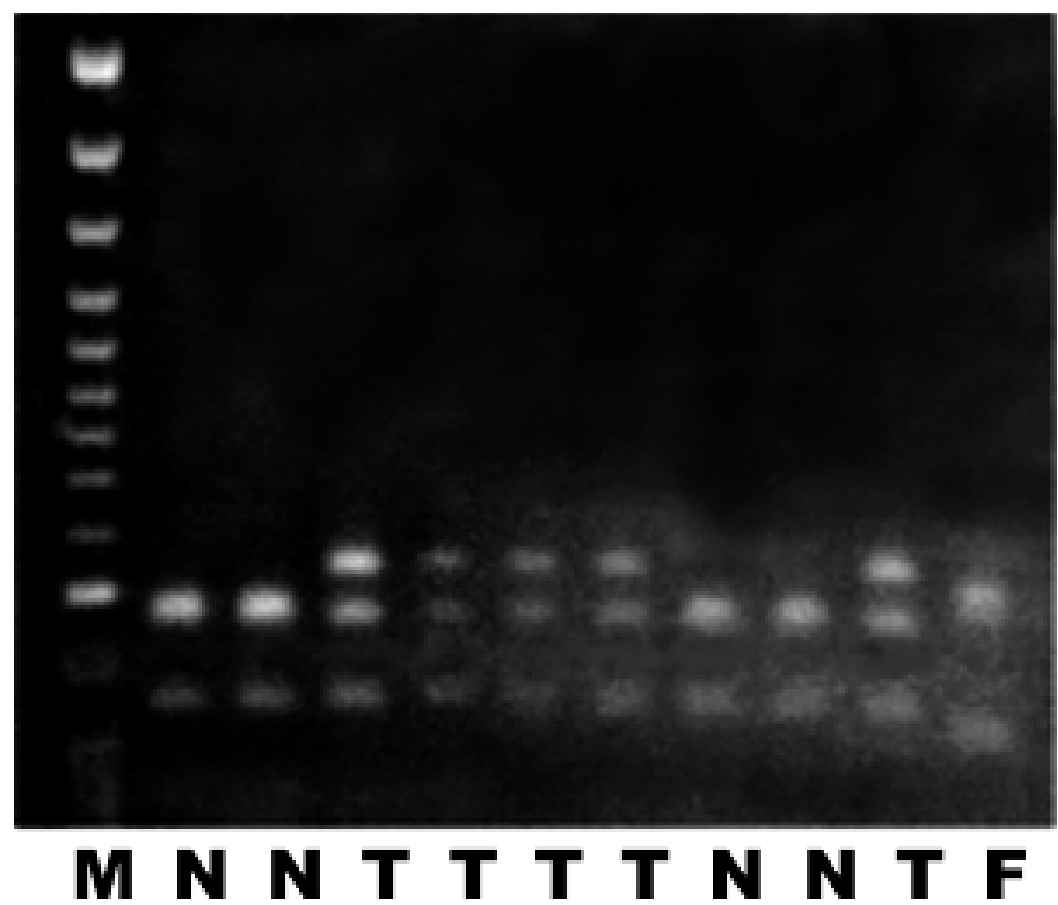

FIGURE 2. Digestion of the chloroplast DNA region $\operatorname{trn} \mathrm{T}-\operatorname{trn} \mathrm{F}$ with restriction enzyme AluI for Saxifraga nivalis (N), S. tenuis $(\mathrm{T})$ and $S$. foliolosa $(\mathrm{F})$. The first lane contains a 100 bp DNA size marker $(\mathrm{M})$. Note absence of the upper band on $S$. nivalis.

\section{Discussion}

The principal component analysis confirms that the $S$. nivalis complex in the Canadian Arctic is represented by two principal morphotypes, appearing as adjacent clusters on the PCA graph. The several plants occupying an intermediate position between the two clusters displayed a somewhat intermediate morphology, but nevertheless could readily be assigned to one of the two taxa. For example, several specimens of $S$. nivalis from Prince Patrick Island (e.g., Gillespie \& Consaul 6869-4, 6926a-3) were very small with slender flowering stems, characters typical of $S$. tenuis, but otherwise had the morphological characteristics of $S$. nivalis. Although character states or ranges overlapped for the majority of characters examined, differences between the two taxa were statistically significant for all quantitative and for three qualitative characters.

\section{Morphological variability}

A significant amount of variance was observed for most characters measured. Since the $S$. nivalis complex is considered an environmental indicator (Aiken et al. 1998, 2000*), the variability observed may be due to phenotypic plasticity and variation in environment. For instance, S. nivalis plants growing in harsher habitats are usually shorter and less robust (e.g., the very short plant shown in Figure 3) than those grow- ing in more nourishing environments. Also plants of $S$. nivalis may be taller with more slender stems in shady microhabitats as a result of etiolation. Another contributor to variance is the time of collection. Since stems elongate in the fruiting stage, particularly in $S$. nivalis, plants collected later in the season are more likely to be taller than their younger counterparts. However, most examined collections of $S$. nivalis and S. tenuis made at the same time and site displayed significant height differences on average between the two taxa. Leaf characters, such as leaf size and teeth number and size, showed much variation both within and between the two taxa. Although $S$. tenuis is usually found in wetter habitats than S. nivalis, the latter species in particular occupies a broad range of habitats and the two species sometimes co-occur in mixed populations. Some of the morphological variation in the complex, particularly within $S$. nivalis, may reflect this variation in habitat (Blondeau and Cayouette 2002; Aiken et al. 2000*). Such high intraspecific variation is apparently typical of Saxifrages, particularly in arctic and alpine environments, and several studies have demonstrated that such variation may not be of taxonomic significance (Soltis et al. 1996; Brysting et al. 1996).

The coloration of petals also varied within each taxon, but season and environment can be a large con- 

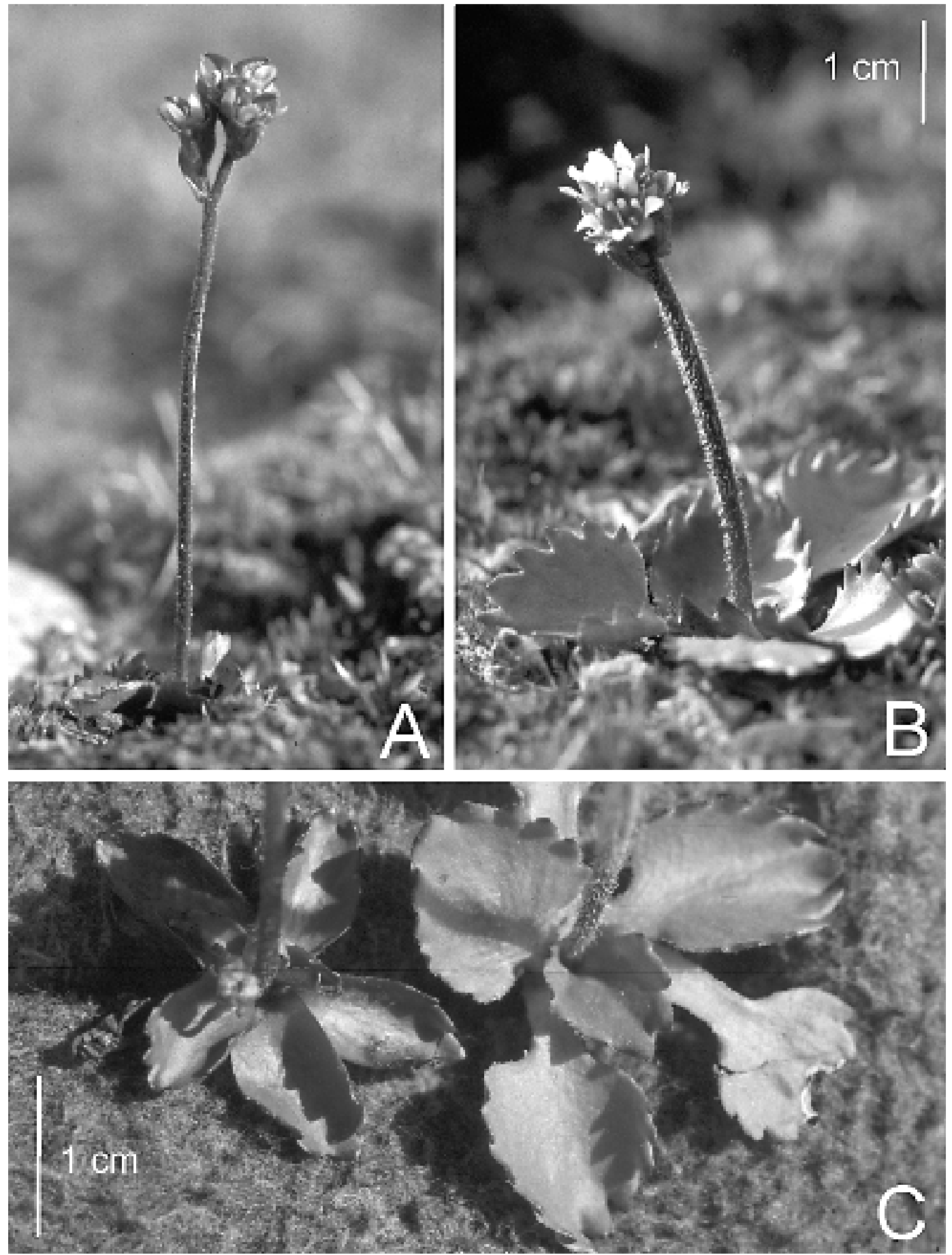

FIGURE 3. Saxifraga nivalis complex in the Canadian Arctic. A. S. tenuis (Gillespie \& Consaul 6978-2), habit. B. S. nivalis (Gillespie and Consaul 6977-1), habit. C. Comparison of basal rosette of leaves of S. tenuis (on left, Gillespie \& Consaul 6978-2) and S. nivalis (on right, Gillespie and Consaul 6977-1). A and B are the same scale. 
tributor to petal coloration. Plants growing in more open, sunnier environments tend to have more pink or dark red anthocyanin pigment throughout the plant, including the petals. White petals may also sometimes turn pinkish with age. In contrast, little variation was observed within each taxon for the texture and coloration of stem hair, and these characters were significantly different between taxa.

Among traits traditionally used for identification of the $S$. nivalis complex, many displayed considerable intrataxon variance, with ranges often overlapping between taxa. Our results also indicate a greater degree of variability within $S$. nivalis than in $S$. tenuis in the Canadian Arctic. This pattern of variation results in a somewhat obscure morphological boundary between the two species and has led to difficulties in constructing good identification keys.

\section{Characters and taxonomic identification}

Despite the considerable intraspecific variation, most commonly used identification characters were significantly different between the two taxa. Indeed, plants of S. nivalis were overall larger and more robust than $S$. tenuis, and the latter often had a more reddish tinge on the petals and stem hair, as previously found by numerous authors (Simmons 1906; Polunin 1940; Porsild 1957; Böcher et al. 1968; Löve 1983; Blondeau 1989a; Webb 1993).

Flowering stem width was an excellent identification character apart from a few individuals, with $S$. tenuis characterized by a width of $1 \mathrm{~mm}$ or less, consistent with Webb's (1993) use of it as a key character. Consistently used by various botanists (e.g., Webb 1993), stem hair characters were among the most useful for identification. Saxifraga nivalis usually has a much more conspicuous, longer, denser, coarse crisped white vestiture, while $S$. tenuis has a less conspicuous, shorter, finer, usually glandular pubescence. Canadian Arctic S. tenuis was found to always have stem hairs, thus not conforming to descriptions of the taxon in Greenland and Svalbard as having mostly glabrous stems (Böcher et al. 1968, 1978; Rønning 1996). Generally, S. nivalis plants were taller than S. tenuis, but due to its variance, height was not useful for identification.

Saxifraga nivalis had more numerous teeth on the leaves than $S$. tenuis, and the latter had rounder obtuse teeth versus more pointed, as suggested in the literature (e.g., Böcher et al. 1968), The width and length of $S$. tenuis teeth were also found to be less than those observed on S. nivalis, but, this is not surprising considering that $S$. nivalis had on average longer and wider leaves. Interestingly, S. nivalis had a notably less regular dentition than $S$. tenuis in regards to the size of the teeth. The former generally had small teeth at the base with teeth becoming larger towards the apex, whereas $S$. tenuis had more evenly sized teeth. Although size of the largest leaf differed significantly between the two taxa, leaf size characters make poor diagnostic characters due to overlap and age related variation. Also, leaf shape varied tremendously and thus should not be considered a good discriminating character. However, the leaf apices of $S$. tenuis did tend to be more rounded than those of $S$. nivalis.

Inflorescence compactness provides a useful identification character, with $S$. nivalis having one or more compact head-like clusters and $S$. tenuis a more open inflorescence (as described in Porsild 1957). Flower pedicels, especially of the lowermost flowers, are longer in $S$. tenuis than in S. nivalis. Since pedicels of the latter may elongate somewhat in fruit, this difference may be obscured later in the season. Although not constant, petals tend to be whiter, wider and ovate in $S$. nivalis and pink, narrower, more elongated and rounder at the apex in S. tenuis. Böcher (1938), Böcher et al. (1968), and more recently Löve (1983) and Rønning (1996) state that $S$. nivalis has straight or slightly spreading styles, while $S$. tenuis has styles that curve strongly downwards. This was not always the case in Canadian Arctic specimens we examined. The way specimens were pressed and the time of collection might be partly responsible for the variation in this character within the two species.

Other characters showed variation that was not useful in separating the two taxa. While $S$. nivalis usually had hairs on leaf margins, this character was also found to a lesser degree in S. tenuis. Most specimens examined had a purplish or reddish stem, thus not specific to $S$. tenuis. Also, the flowering stems of both taxa had on occasion a reduced leaf (bract) or two near the inflorescence, although usually more prominent in S. tenuis.

The presence of rust-coloured hairs on the lower surface of the leaves of $S$. tenuis has been commonly used to distinguish it from S. nivalis in the Canadian Arctic, and was used as a key character by several authors (Porsild 1957; Scoggan 1978; Porsild and Cody 1980). However, this study reveals that hairs are present on the leaf undersurface in over $99 \%$ of the plants examined of both species in the Canadian Arctic, and that hairs may be rust-coloured in both species, about $42 \%$ of $S$. nivalis plants examined and $74 \%$ of $S$. tenuis plants. This error may have resulted from Porsild's inclusion of $S$. rufopilosa within his concept of $S$. tenuis (distribution maps of S. tenuis in Porsild (1957) and Porsild and Cody (1980) appear to have included S. rufopilosa). Saxifraga rufopilosa, a species now considered to be endemic to unglaciated areas of the Yukon and Alaska, is characterized by a mat of long crinkly rusty hairs on the leaf undersurface (Cody 1996), much longer and denser than in either S. tenuis or S. nivalis. Whatever its origin, use of rust-coloured hair presence as a key diagnostic character in identifying Canadian Arctic material of the S. nivalis complex resulted in many misidentified specimens and much confusion as to the identity of $S$. tenuis. 

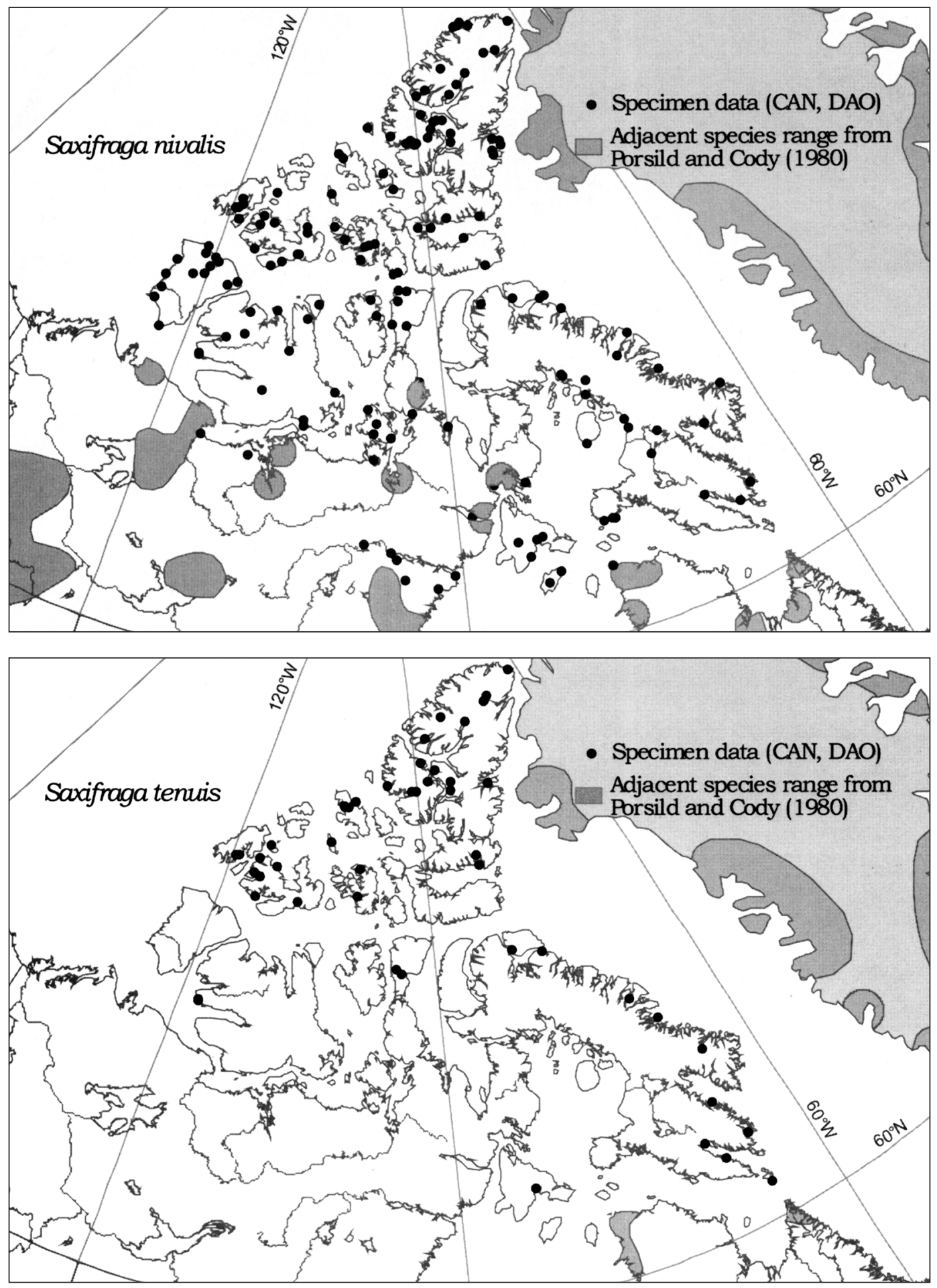

FIgURE 4. Distribution of the Saxifraga nivalis complex in the Canadian Arctic. (above) S. nivalis. (below) S. tenuis. Shading indicates approximate distribution outside of the Arctic Islands (from Porsild and Cody 1980, and CAN and DAO herbarium records). 
The many herbarium collections having both $S$. nivalis and $S$. tenuis plants on the same sheet and under the same number (e.g., Bruggeman 358, Savile 4562, Macdonald 150, Calder et al. 24149) shows just how problematic identification of this complex in the Canadian Arctic has been. About $20 \%$ of herbarium specimens identified as $S$. tenuis at both CAN and DAO were in fact mixed collections including both $S$. tenuis and $S$. nivalis plants, or less often including small plants of $S$. foliolosa or $S$. hieracifolia Waldst. \& Kit. Previous identification problems of the $S$. nivalis complex in the Canadian Arctic may also have been due to misinterpretation of key characters. For example, $S$. nivalis with several flower heads could be keyed out under lax (open) inflorescence.

Although $S$. nivalis and $S$. tenuis can be readily distinguished in the Canadian Arctic, a small percentage of specimens had one or a few characteristics of the other species. For example, some high arctic S. nivalis had very slender stems or fruit with strongly recurved styles. While this may be part of the natural variation within S. nivalis, it may also suggest a low level of hybridization. Some of the overlap in quantitative character states shown in our morphological analyses may also be the result of hybridization. Recent cytological studies have suggested the existence of S. nivalis-S. tenuis hybrids $(2 \mathrm{n}=40)$ in regions of the Russian Arctic and the Yukon where S. nivalis and S. tenuis are found growing together (Krause and Beamish 1973; Devyatov et al. 1997). The population in the Gaspé Peninsula has the same intermediate chromosome number and may represent a stabilized relictual hybrid in an area whether neither parent now occurs (Gervais et al. 1995). In addition Polunin (1959) suggested that hybridization may also occur between the $S$. nivalis complex and other closely related species, such as $S$. hieracifolia.

\section{Geographical variation in Saxifraga tenuis}

Savile (1961) proposed that North American S. tenuis may be divided into three disjunct and morphologically distinct "populations." The first is a high arctic population composed of plants identical to material from the north of Greenland and hypothesized to have spread from there following the Pleistocene. The second population is apparently found mostly along Hudson Straight in southern Baffin Island, northernmost Quebec and Southampton Island, but also scattered northward to northeast Baffin Island. Savile treated plants in the Gaspé Peninsula of Quebec, considered by some as a separate species $S$. gaspensis, as part of this population. Plants of this population apparently tend to be larger and less purplish in colour than in the high arctic. The third highly variable population, found in Alaska and the Yukon, is usually characterized by a highly purplish pigmentation and whitish scape hairs, and was suggested to be intermediate between $S$. nivalis and high arctic $S$. tenuis.
Our analysis indicates that eastern and high arctic plants of $S$. tenuis cannot be distinguished based on examined quantitative characters, while western montane plants (based on our small sample size) may be differentiated from most arctic plants based on larger size. Since Savile (1961) used mostly qualitative characters to distinguish the three groups, further analyses based on both qualitative and quantitative characters and including more western montane and eastern arctic specimens should be made to further test his hypothesis.

\section{Chloroplast DNA analysis}

The five non-coding cpDNA regions of $S$. nivalis and $S$. tenuis were identical for restriction sites assayed. Considering the conservative nature of cpDNA evolution, it is not surprising to observe such similarity, with closely related species often having identical cpDNA restriction site profiles (Olmstead and Palmer 1994). However, S. nivalis and $S$. tenuis displayed an estimated 50 bp length difference in the $\operatorname{trnT}$-trnF region. This difference was observed both among plants from the same site and from different locations. This suggests that the size variation in the $\operatorname{trn} \mathrm{T}-\operatorname{trn} \mathrm{F}$ region is not background variation among populations or a phenomenon limited to a particular population, but represents a molecular difference between $S$. nivalis and $S$. tenuis, either a deletion event in S. nivalis or an insertion event in $S$. tenuis. Sequencing of the $\operatorname{trn} \mathrm{T}-\operatorname{trn} \mathrm{F}$ region would prove useful in specifying the nature of this size difference. The RFLP analysis revealed molecular differences for 16 of 105 restriction enzyme assays between $S$. foliolos $a$ and the other two species. These results are similar to a study of Saxifraga based on the cpDNA matK sequences (Soltis et al. 1996; plus sequences in Genbank), in which $S$. nivalis and $S$. tenuis would appear to be more closely related to each other than to $S$. foliolosa. Based on comparison of the Genbank sequences, the single plant of $S$. tenuis differed from $S$. nivalis in four nucleotide substitutions, and from $S$. foliolosa in 79 substitutions.

\section{Implications}

Our results suggest that $S$. nivalis and $S$. tenuis should be recognized as distinct taxa, and are most appropriately recognized at the species level following Porsild (1957), Porsild and Cody (1980), and Webb (1993). The two taxa are distinguishable at both the molecular and cytological level and have morphological differences that correspond to these differences. Although no morphological characters give $100 \%$ separation, many quantitative and qualitative characters show statistically significant differences between the two taxa. The two taxa overlap in geographic distribution in the Canadian Arctic, with the range of the less common $S$. tenuis included within that of $S$. nivalis. Although ranges of habitat preferences differ, there is considerable overlap, with the two taxa sometimes occurring in mixed populations. Lack of geographical 
separation and considerable habitat overlap make recognition at the subspecific level inappropriate, while the morphological distinctiveness of the two taxa would make recognition at the varietal level inappropriate.

\section{Saxifraga nivalis complex in the Canadian Arctic: key to species}

A. Inflorescence one to several dense head-like clusters of numerous flowers; petals white or essentially so (sometimes becoming pink with age); flowering stem (0.5-) 1-2.5 mm wide, moderately to densely hairy, with conspicuous long coarse white hairs; plant usually robust in appearance

S. nivalis

B. Inflorescence an open cyme of fewer flowers, flowers on distinct pedicels; petals pink or less often white; flowering stem $0.3-1 \mathrm{~mm}$ wide, usually sparsely hairy, with short fine hairs that are usually inconspicuous; plant delicate in appearance

S. tenuis

\section{Saxifraga nivalis $\mathbf{L}$.}

Plants perennial herbs, (2) 5-17 cm high, with a basal rosette of leaves. Leaves simple, alternate, all basal in a rosette, evergreen; petiole usually distinct, $0.2-2.5 \mathrm{~mm}$ long. Leaf blade ovate, obovate, orbicular or spatulate, 6-36 mm long (mean $14 \mathrm{~mm}$ ), 4-21 mm wide (mean $10 \mathrm{~mm}$ ), slightly leathery; green above, green or reddish-purple beneath, base obtuse and usually abruptly narrowed at petiole; apex obtuse, rounded or rarely acute; appearing single-veined or with inconspicuous lateral veins; upper surface glabrous; lower surface sparsely to densely hairy; hairs 0.2-1.2 mm long, rust-coloured, whitish or translucent; margins coarsely serrate or crenate, usually with rust-coloured or whitish hairs; teeth 7-14, usually increasing in size towards blade apex, tips usually pointed. Flowering stem erect, (0.5) 1-2.5 mm wide, green to purple, moderately to densely hairy, with hairs conspicuous, (0.5) 0.7-1.2 mm long, crisped (crinkly and irregularly wavy), white or translucent with tips and crosswalls white or sometimes rust-coloured or purplish, the tips sometimes glandular, usually leafless or occasionally with reduced leaves (bracts) close to the inflorescence. Inflorescence a dense head-like cluster of numerous flowers, sometimes with 1-2 smaller lateral clusters on short to long peduncles; flowers on very short pedicels, subtended by bracts. Flowers: sepals 5, free, green or purple, glabrous; petals 5, ovate or elliptic, $0.7-1.8 \mathrm{~mm}$ wide, equal to or longer than the sepals, white or cream-coloured, sometimes with reddish apex, mostly obtuse at apex; stamens 10 ; gynoecium partly inferior; carpels 2, partly fused; styles 2, free; placentation axile; ovules numerous. Fruit a capsule, spherical in lower half, with straight or slightly divergent free carpels above, 3-4 mm long, 4.5-5.5 mm wide, glabrous, dry, dehiscent; styles straight or slightly divergent, persistent; sepals persistent in fruit. Seeds numerous, $0.5-1 \mathrm{~mm}$ long, yellowish brown, with surface verrucose. Figure $3 b$, c; map $4 \mathrm{a}$.

\section{Saxifraga tenuis (Wahlenb.) Harry Sm.}

Plants perennial herbs, $2-9 \mathrm{~cm}$ high, with a basal rosette of leaves. Leaves simple, alternate, all basal in a rosette, evergreen; petiole usually indistinct, $\sim 0.5-2.5 \mathrm{~mm}$ long. Leaf blade narrowly ovate, obovate or spatulate, 4-15 $\mathrm{mm}$ long (mean $7 \mathrm{~mm}$ ), 2-8 mm wide (mean $5 \mathrm{~mm}$ ); slightly leathery, green to reddish-purple above, reddish-purple beneath; base obtuse or broadly attenuate and decurrent onto petiole; apex obtuse, rounded or rarely acute; appearing single-veined or with inconspicuous lateral veins; upper surface glabrous; lower surface usually sparsely hairy, with hairs 0.1-0.4 mm long, rust-coloured, whitish or translucent; margins coarsely serrate or crenate, with sparse rust-coloured or whitish hairs or sometimes glabrous; teeth 6-9, usually evenly sized, tips usually rounded. Flowering stem erect, 0.3-1 mm wide, usually dark purple, sparsely hairy, with hairs mostly inconspicuous, 0.1 $0.3(0.5) \mathrm{mm}$ long, fine, crinkled or straight, rust-coloured to translucent, often with purplish crosswalls and tips, the tips usually glandular; sometimes with a reduced leaf (bract) on the upper part of the stem. Inflorescence an open head of few flowers; flowers subtended by bracts; lower-most flowers often long-pedicellate and each subtended by a conspicuous bract. Flowers: sepals 5, free, green or purple, glabrous; petals 5 , ovate or elliptic, 0.5-1.1 mm wide, equal to or longer than the sepals, usually pink, sometimes white, often with reddish apex, often rounded at apex; stamens 10; gynoecium partly inferior; carpels 2, partly fused; styles 2, free; placentation axile; ovules numerous. Fruit a capsule, spherical in lower half, with diverging free carpels above, 3-4 mm long, 4.5-5.5 mm wide, glabrous, dry, dehiscent; styles usually strongly re-curved at maturity, persistent; sepals persistent in fruit. Seeds numerous, $0.5-1 \mathrm{~mm}$ long, yellowish brown, with surface verrucose. Figure 3a, c; map 4b.

\section{Acknowledgments}

We thank Kristina Makkay for assistance with the statistical analysis and figures; Laurie Consaul for suggestions in statistical analysis and assistance with mapping; Michelle Leblanc for assistance with mapping; Susan Aiken for interesting discussions; Gisèle Mitrow and William J. Cody for assistance at the DAO herbarium. Also, a special thank-you to Marcel Blondeau from the Université Laval for sharing his knowledge and insights on the Saxifraga nivalis complex. We acknowledge and thank Polar Continental Shelf Project, Nunavut Research Institute and Aurora Research Institute for their logistic support in the field. This paper is based on a fourth year honours thesis project by C. H. submitted to the Biology Department, University of Ottawa.

Documents Cited (marked $*$ in text).

Aiken, S. G., M. J. Dallwitz, L. L. Consaul, C. L McJannet, L. J. Gillespie, R. L. Boles, G. W. Argus, J. M. Gillett, P. J. Scott, R. Elven, M. C. LeBlanc, and A. E. Zamluk. 2000. Flora of the Canadian Arctic Archipelago: Descriptions, Illustrations, Identification, and Information Retrieval. (version 16 November 2000) http://www.keil.ukans. edu/delta/

Aiken, S. G., M. J. Dallwitz, L. L. Consaul, C. L. McJannet, L. J. Gillespie, R. L. Boles, G. W. Argus, J. M. Gillett, P. J. Scott, R. Elven, M. C. LeBlanc, and A. E. Zamluk. 2002. Flora of the Canadian Arctic Archipelago: Descriptions, Illustrations, Identification, and Information Retrieval. (version 14 August 2002) http://www.mun.ca/ biology/delta/arcticf/

\section{Literature Cited}

Aiken, S. G. M. J. Dallwitz, C. L. McJannet, L. J. Gillespie, and L. L. Consaul. 1998. Saxifragaceae of the Canadian Arctic Archipelago: a contribution to a DELTA database for interactive identification and illustrated infor- 
mation retrieval. Canadian Journal of Botany 76: 20202036.

Arnold, M. L., C. M. Buckner, and J. J. Robinson. 1991. Pollen-mediated introgression and hybrid speciation in Louisiana irises. Proceedings of the National Academy of the United States of America 88: 1398-1402.

Blondeau, M. 1989a. La flore vasculaire de la région d'Ivujivik incluant Wolstenholme (Nouveau-Québec) et les îles Digges (Territoires du Nord-Ouest). Provancheria 22: 1102.

Blondeau, M. 1989b. La flore vasculaire des environs d'Akulivik, Nouveau-Québec. Provancheria 23: 1-80.

Blondeau, M., and J. Cayouette. 2002. La flore vasculaire de la baie Wakeham et du Havre Douglas, détroit d'Hudson, Nunavik, Québec. Provancheria 28: 1-184.

Böcher, T. W. 1938. Biological distributional types in the flora of Greenland. Meddelelser om Grønland 106: 1-339.

Böcher, T. W., K. Holmen, and K. Jakobsen. 1968. The Flora of Greenland. English edition. P. Haase and Son. Copenhagen, Denmark.

Böcher, T. W., B. Fredskild, K. Holmen, and K. Jakobsen. 1978. Grønlands Flora. $3^{\text {rd }}$ edition. P. Haase and Sons, Copenhagen, Denmark.

Boivin, B. 1966. Énumération des plantes du Canada. III. Herbidées. Naturaliste canadien 93: 585-646.

Britton, N., and A. Brown. 1913. An Illustrated Flora of the Northern United States, Canada and the British Possessions. Volume 2. $2^{\text {nd }}$ edition. Charles Scribner's Sons, New York.

Brysting, A. K., T. M. Gabrielsen, O. Sørlibråten, O. Ytrehorn, and C. Brochmann. 1996. The purple saxifrage, Saxifraga oppositifolia, in Svalbard: two taxa or one? Polar Research 15: 93-105.

Cody, W. J. 1996. Flora of the Yukon Territory. National Research Council Research Press, Ottawa, Canada. 646 pages.

Dallwitz, M. J., T. A. Paine, and E. J. Zurcher. 1993. DELTA User's Guide: a general system for processing taxonomic descriptions. $4^{\text {th }}$ edition. CSIRO Division of Entomology, Canberra, Australia.

Demesure B., N. Sodzi, and R. J. Petit. 1995. A set of universal primers for amplification of polymorphic non-coding regions of mitochondrial and chloroplast DNA in plants. Molecular Ecology 4: 129-131.

Devyatov, A. G., P. Y. Zhmylev, and A. D. Kozhevnikova. 1997. Chromosome numbers of some arctic species of the genus Saxifraga (Saxifragaceae). Botanical Zhurnal 82: $122-129$.

Doyle, J. J., and J. L. Doyle. 1990. Isolation of plant DNA from fresh tissue. Focus 12: 13-15.

Dumoulin-Lapegue, S., M.-H. Pemonge, and R. J. Petit. 1997. An enlarged set of consensus primers for the study of organelle DNA in plants. Molecular Ecology 6: 393-397.

Fernald, M. L. 1917. New species, varieties and forms of Saxifraga. Rhodora. 19: 141-144.

Fernald, M. L. 1950. Gray's Manual of Botany, $8^{\text {th }}$ edition. American Book Co., New York.

Gervais, C., N. Dignard, and R. Trahan. 1995. The chromosome number of Saxifraga gaspensis Fernald. Rhodora 97: 171-175.

Gillespie, L. J., L. L. Consaul, and S. G. Aiken. 1997. Hybridization and the origin of the arctic grass Poa hartzii (Poaceae): evidence from morphology and chloroplast DNA restriction site data. Cananadian Journal of Botany 75: 1978-1997.
Gillespie, L. J., and R. Boles. 2001. Phylogenetic relationships and infraspecific variation in Canadian Arctic Poa based on chloroplast DNA restriction site data. Canadian Journal of Botany 79: 679-701.

Haworth, A. H. 1812. Synopsis Plantarum Succulentarum. Richard Taylor, London, United Kindom.

Hedberg, O. 1967. Chromosome numbers of vascular plants from arctic and subarctic North America. Arkiv för Botanik 6: 309-326.

Hultén, E. 1945. Flora of Alaska and Yukon. Volume 5. Gleerup, Lund, Sweden.

Hultén, E. 1968. Flora of Alaska and neighboring territories. Stanford University Press, Stanford, California.

Johnson, A. W., and J. G. Packer. 1968. Chromosome numbers in the flora of Ogotoruk Creek, N. W. Alaska. Botaniska Notiser 121: 403-456.

Krause, D. L., and K. I. Beamish. 1973. Notes on Saxifraga occidentalis and closely related species in British Columbia. Syesis 6: 105-113.

Lindman, C. A. M. 1918. Svensk Fanerogamflora. P. A. Norstedt and Söners Förlag, Stockholm, Sweden.

Linnaeus, C. 1753. Species Plantarum. Holmiae, Impensis L. Salvii.

Löve, À. 1983. Flora of Iceland. Revised English edition. Almenna Bókafélagid, Reykjavík, Iceland.

Löve, À., and D. Löve. 1975. Cytotaxonomical Atlas of the Arctic Flora. Cramer, Vaduz, Liechtenstein.

Mosquin, T., and D. E. Hayley. 1966. Chromosome numbers and taxonomy of some Canadian Arctic plants. Canadian Journal of Botany 44: 1209-1218.

Olmstead, R. G., and J. D. Palmer. 1994. Chloroplast DNA systematics: a review of methods and data analysis. American Journal of Botany 81: 1205-1224.

Packer, J. G., and G. D. McPherson. 1974. Chromosome numbers in some vascular plants from northern Alaska. Canadian Journal of Botany 52: 1095-1099.

Polunin, N. 1940. Botany of the Canadian Eastern Arctic. Part I. National Museum of Canada, Bulletin 92.

Polunin, N. 1959. Circumpolar Arctic Flora. Clarendon Press, Oxford, United Kingdom.

Porsild, A. E. 1957. Illustrated flora of the Canadian Arctic Archipelago. National Museum of Canada, Bulletin 146.

Porsild, A. E. 1964. Illustrated flora of the Canadian Arctic Archipelago. $2^{\text {nd }}$ edition. National Museum of Canada, Bulletin 146.

Porsild, A. E. 1975. Materials for a Flora of Central Yukon Territory. Publications in Botany 4. National Museum of Canada, Ottawa, Canada..

Porsild, A. E., and W. J. Cody. 1980. Vascular Plants of the Continental Northwest Territories, Canada. National Museum of Canada, Ottawa, Canada.

Rønning, O. I. 1996. The Flora of Svalbard. Norwegian Polar Institute, Oslo, Norway.

Savile, D. B. O. 1961. The botany of the northwestern Queen Elizabeth Islands. Canadian Journal of Botany 39: 909942.

Scoggan, H. J. 1950. The flora of Bic and the Gaspe Peninsula, Quebec, Canada. National Museum of Canada, Bulletin 115.

Scoggan, H. J. 1978. The Flora of Canada. Publications in Botany 7. National Museum of Natural Sciences, National Museums of Canada, Ottawa, Canada.

Simmons, H. G. 1906. The vascular plants in the flora of Ellesmereland. Report of the second Norwegian arctic ex- 
pedition in the "Fram" 1898-1902. Number 2. Videnskabs Selkabet i Kristiania, Kristiana, Norway.

Small, J. K., and P. A. Rydberg. 1905. Saxifragaceae. Pages 81-158 in North American Flora. Volume 22. New York Botanical Garden, New York.

Soltis, D. E., D. R. Morgan, A. Grable, P. S. Soltis, and R. Kuzoff. 1993. Molecular systematics of Saxifragaceae sensu stricto. American Journal of Botany 80: 10561076.

Soltis, D. E, R. K. Kuzoff, E. Conti, R. Gornall, and K. Ferguson. 1996. MatK and $r b c \mathrm{~L}$ gene sequence data indicate that Saxifraga (Saxifragaceae) is polyphyletic. American Journal of Botany 83: 371-382

Spongberg, S. A. 1972. The genera of Saxifragaceae in the south-eastern United States. Journal of the Arnold Arboretum 53: 409-498.

Taberlet, P., L. Gielly, G. Pautou, and J. Bouvet. 1991. Universal primers for the amplification of three non-coding regions of the chloroplast DNA. Plant Molecular Biology. 17: 1105-1109.

Wahlenberg, G. 1812. Flora Lapponica. Taberna Libraria Scholae realis, Berlin, Germany.

Webb, D. A. 1964. Saxifraga. Pages 364-380 in Flora Europaea. Volume 1. Edited by T. G. Tutin, V. H. Heywood, N. A Burges, D. H. Valentine, S. M. Walters, and D. A. Webb. Cambridge University Press, Cambridge, United Kingdom.

Webb, D. A. 1993. Saxifraga. Pages 437-458 in Flora Europaea. $2^{\text {nd }}$ edition. Volume 1. Edited by T. G. Tutin, N. A. Burges, A. O. Chater, J. R. Edmondson, V. H. Heywood, D. M. Moore, D. H. Valentine, S. M. Walters, and D. A. Webb. Cambridge University Press, Cambridge, United Kingdom.

Received 4 February 2003

Accepted 7 December 2004

Appendix 1: Collections examined of the Saxifraga nivalis complex from the Canadian Arctic.

\section{Saxifraga nivalis}

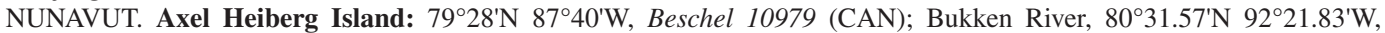

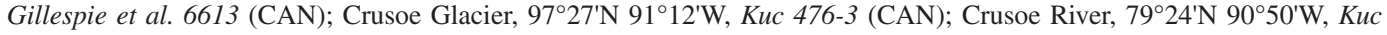

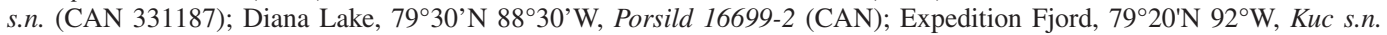
(CAN 331189, CAN 331189); Mesa Brook, 79³7'N 95 W, Beschel 13129 (CAN); Mokka Fiord, $79^{\circ} 45^{\prime} \mathrm{N} 87^{\circ} \mathrm{W}$, Parker $^{\circ}$

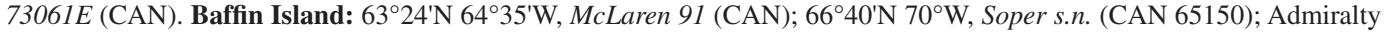

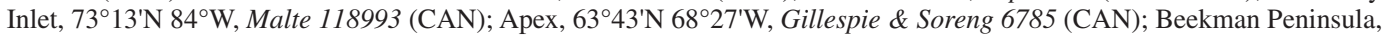

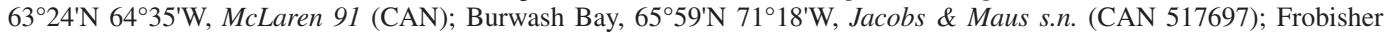

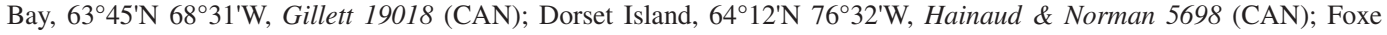

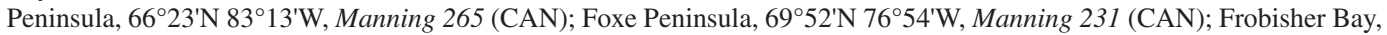
$62^{\circ} 57^{\prime} \mathrm{N} 66^{\circ} 03^{\prime} \mathrm{W}$, Aiken et al. 86-260 (CAN); Frobisher Bay, 63⒋ $44^{\prime} \mathrm{N} 68^{\circ} 27^{\prime} \mathrm{W}$, Aiken et al. 86-493 (CAN); Frobisher Bay, $62^{\circ} 57^{\prime} \mathrm{N} 66^{\circ} 03^{\prime} \mathrm{W}$, Calder et al. s.n. (DAO 24148); Frobisher Bay, 62 $57^{\prime} \mathrm{N} 66^{\circ} 03^{\prime} \mathrm{W}$, Wynne-Edwards 7353 (CAN); Pond Inlet, $72^{\circ} 50^{\prime} \mathrm{N} 76^{\circ} 40^{\prime} \mathrm{W}$, Dutilly 1224a (CAN); Stising Valley, Weber 94 (CAN); Taverner Bay, 67 $12^{\prime} \mathrm{N} 72^{\circ} 25^{\prime} \mathrm{W}$, Manning $^{\prime}$ 44, 68, 77 (CAN). Bathurst Island: Polar Bear Pass, 7543'N 98 23'W, Aiken \& Maus 92-022 (CAN); Goodsir Inlet, $75^{\circ} 45^{\prime} \mathrm{N} 97^{\circ} 45^{\prime} \mathrm{W}$, Lamothe 69-25 (CAN); Polar Bear Pass, 7543.8' $98^{\circ} 25.45^{\prime} \mathrm{W}$, Gillespie \& Consaul 6984 (CAN) [DNA voucher, individuals 1-5 examined]. Bylot Island: $72^{\circ} 53^{\prime} \mathrm{N} 76^{\circ} \mathrm{W}$, Wilcox 125631 (CAN). Cameron Island: $76^{\circ} 19.5^{\prime} \mathrm{N}$ $104.5^{\circ} \mathrm{W}$, Aiken 92-039 (CAN). Cornwallis Island: Resolute, 7440'N 94 50'W, Aiken \& MacCormac 98-055 (CAN 581909, plants 1-5; CAN 582554); Resolute, $74^{\circ} 40^{\prime} \mathrm{N} 95^{\circ} 04^{\prime} \mathrm{W}$, Aiken et al. 93-072 (CAN). Devon Island: Dundas Harbour, $74^{\circ} 31.3^{\prime} \mathrm{N} 82^{\circ} 33.5^{\prime} \mathrm{W}$, Gillespie et al. 6675-1 (CAN); Truelove Lowland, $75^{\circ} 40^{\prime} \mathrm{N} 84^{\circ} 40^{\prime} \mathrm{W}$ Kerik s.n. (CAN

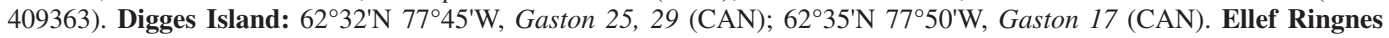
Island: Isachsen, $78^{\circ} 47^{\prime} \mathrm{N} 103^{\circ} 50^{\prime} \mathrm{W}$, Macdonald 242 (CAN). Ellesmere Island: $79^{\circ} 34^{\prime} \mathrm{N} 84^{\circ} 44^{\prime} \mathrm{W}$, Edlund \& Roncato-

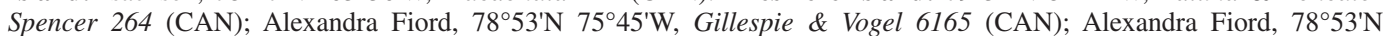
$75^{\circ} 50^{\prime} \mathrm{W}$, Gillett \& Shchepanek $18108(\mathrm{CAN})$; Craig Harbour, $76^{\circ} 20^{\prime} \mathrm{N} 81^{\circ} 30^{\prime} \mathrm{W}$, Dutilly 1267 (CAN); Hazen, $68^{\circ} 30^{\prime} \mathrm{N}$

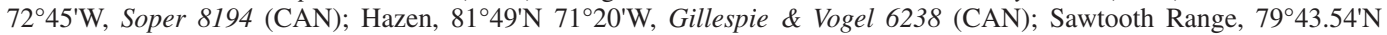

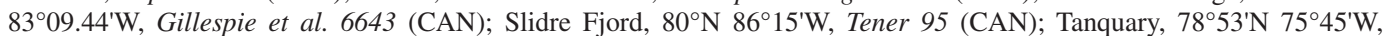
Gillespie \& Vogel 5982 (CAN). King William Island: Gjoa Haven, Cooper 28 (CAN), 73 (CAN), 226 (CAN); Gjoa Haven, 68 $38^{\prime} \mathrm{N} 95^{\circ} 53^{\prime} \mathrm{W}$, Larson 25 (CAN); Victory Point, Cooper 164 (CAN), 122 (CAN). Lougheed Island: $77^{\circ} 30^{\prime} \mathrm{N}$ $105^{\circ} 38^{\prime} \mathrm{W}$, Edlund 2091 (CAN). Meighen Island: $79^{\circ} 55^{\prime} \mathrm{N} 99^{\circ} 30^{\prime} \mathrm{W}$, Kuc (CAN 331171). Pelly Bay: $68^{\circ} 53^{\prime} \mathrm{N} 89^{\circ} 51^{\prime} \mathrm{W}$, Campbell s.n. (CAN 282778). Prince Charles Island: $67^{\circ} 10^{\prime} \mathrm{N} 76^{\circ} 43^{\prime} \mathrm{W}$, Baldwin 1919 (CAN). Victoria Island: $68^{\circ} 53^{\prime} \mathrm{N}$ $105^{\circ} \mathrm{W}$, Edlund \& Argus 12730-1 (CAN).

NORTHWEST TERRITORIES. Banks Island: $73^{\circ} \mathrm{N} 117^{\circ} \mathrm{W}$, Aiken $99-203$ (CAN); $73^{\circ} 24^{\prime} \mathrm{N} 117^{\circ} 0^{\prime} \mathrm{W}$, Porsild 17711 $(\mathrm{CAN}) ; 74^{\circ} 31^{\prime} \mathrm{N} 121^{\circ} 07^{\prime} \mathrm{W}$, Manning \& Macpherson $164(\mathrm{CAN})$; Bernard River, $73^{\circ} 22^{\prime} \mathrm{N} 121^{\circ} 47^{\prime} \mathrm{W}$, Maher \& Maclean 75 (CAN); Egg River, $72^{\circ} 27^{\prime} \mathrm{N} 124^{\circ} 36^{\prime} \mathrm{W}$, Lambert s.n. (CAN 535943); Lambton, $71^{\circ} 05^{\prime} \mathrm{N} 123^{\circ} 09^{\prime} \mathrm{W}$, Porsild 17579 (CAN); Shoran Lake, $71^{\circ} 51^{\prime} \mathrm{N} 113^{\circ} 23^{\prime} \mathrm{W}$, MacInnes s.n. (CAN 535570, 535598, 535733). Fitzwilliam Owen Island: $77^{\circ} 07^{\prime} \mathrm{N}$ $113^{\circ} 47^{\prime} \mathrm{W}$, Kuc s.n. (CAN 331114). Melville Island: $75^{\circ} 56^{\prime} \mathrm{N} 114^{\circ} 48^{\prime} \mathrm{W}$, Edlund \& Aiken 148 (CAN); Canrobert Hills

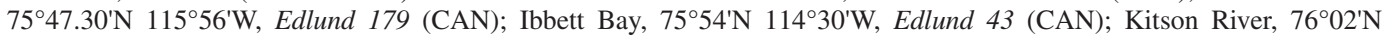
$113^{\circ} 05^{\prime} \mathrm{W}$, Edlund 18 (CAN); Marie Bay $76^{\circ} 12^{\prime} \mathrm{N} 114^{\circ} 55^{\prime} \mathrm{W}$, Edlund 305 (CAN); McCormick Inlet, $75^{\circ} 46.2^{\prime} \mathrm{N}$ $112^{\circ} 31.64^{\prime} \mathrm{W}$, Gillespie \& Consaul 6977 (CAN, plants 1, 2), $6964 a(\mathrm{CAN})$; Shellabear Point, $71^{\circ} 51^{\prime} \mathrm{N} 113^{\circ} 23^{\prime} \mathrm{W}$, Edlund $^{\circ}$ 115 (CAN); Sherard Bay, 76 $08^{\prime} \mathrm{N} 108^{\circ} 07^{\prime} \mathrm{W}$, Dugal s.n. (CAN 535598); Winter Harbour, $74^{\circ} 17^{\prime} \mathrm{N} 110^{\circ} 42^{\prime} \mathrm{W}$, Kuc s.n. (CAN 400104); Winter Harbour, $74^{\circ} 17^{\prime} \mathrm{N} 110^{\circ} 42^{\prime} \mathrm{W}$, Tener \& Harington 149 (CAN). Prince Patrick Island: Green Bay, 76³3.67'N 118 53.09'W, Gillespie \& Consaul 6869 (CAN, plants 1-6); Intrepid Inlet, 76²2.01'N 118 35.45'W, Gillespie 


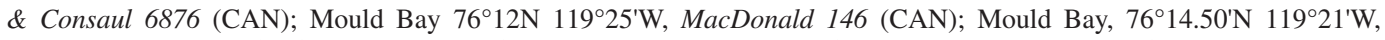
Gillespie \& Consaul 6806 (CAN, plants 1-5); Mould Bay, 76²14'N 118 57'W, Gillespie \& Consaul 6827 (CAN, plants 1, 2), 6826 (CAN, plants a1-a5); Mould Bay, $76^{\circ} 21.50^{\prime} \mathrm{N} 119^{\circ} 30.50^{\prime} \mathrm{W}$, Gillespie \& Consaul 6884 (CAN, plants 1, 2), 6984 (CAN, plants 1-5), 6806 (CAN, plants 1-5). Victoria Island: Minto, 71 $34^{\prime} \mathrm{N} 115^{\circ} 21^{\prime} \mathrm{W}$, Edlund 594 (CAN).

\section{Saxifraga tenuis}

NUNAVUT. Axel Heiberg Island: Bastion Ridge, 79²1'N 9048'W, Beschel 12920 (CAN); Mesa Brook, 79³5'N

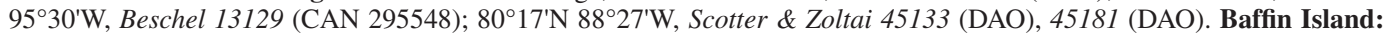
Resolution Island, $61^{\circ} 20^{\prime} \mathrm{N} 64^{\circ} 55^{\prime} \mathrm{W}$, Wynne-Edwards 7225 (CAN); Erik Harbour, $72^{\circ} 40^{\prime} \mathrm{N} 76^{\circ} 30^{\prime} \mathrm{W}$, Calder s.n. (DAO

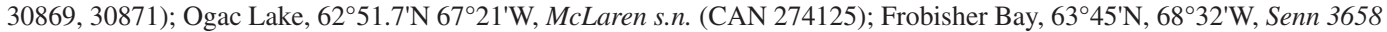
(DAO); Blackhead Island, 645' ${ }^{\prime} \mathrm{N} 66^{\circ} 19^{\prime} \mathrm{W}$, Soper s.n. (CAN 125598); Savage Islands, $61^{\circ} 49.15^{\prime} \mathrm{N} 65^{\circ} 42.62^{\prime} \mathrm{W}$, Gillespie et al. $6728(\mathrm{CAN}), 6732(\mathrm{CAN})$; Inugsuin Fjord, $69^{\circ} 50^{\prime} \mathrm{N} 69^{\circ} 08^{\prime} \mathrm{W}$, Beschel $3649 \mathrm{~A}(\mathrm{CAN})$. Bathurst Island: $76^{\circ} 36^{\prime} \mathrm{N}$ $100^{\circ} 04^{\prime} \mathrm{W}$, Blake $24 a$ (DAO). Bylot Island: $73.03^{\prime} \mathrm{N}$ 80.07'W, Scotter \& Zoltai 6751A (DAO). Ellef Ringnes Island: Isachsen, 7849'N 1033' W, Savile 4275 (DAO), 4219 (DAO), 4224 (DAO), 4285 (DAO), 4355 (DAO), 4293 (DAO); Isachsen, $78^{\circ} 47^{\prime} \mathrm{N} 103^{\circ} 30^{\prime} \mathrm{W}$, MacDonald 251 (CAN), 252 (CAN); Christopher Peninsula, 7859'N 101³5'W, Savile 4194 (DAO); $78^{\circ} 45^{\prime} \mathrm{N} 102^{\circ} 50^{\prime} \mathrm{W}$, Savile 4148 (DAO). Ellesmere Island: Eureka, 7959'N 8550'W, Scotter \& Zoltai 45294-B (DAO); Eureka, $80^{\circ} 10^{\prime} \mathrm{N}, 85^{\circ} 39^{\prime} \mathrm{W}$, Bruggemann 805 (DAO); Fosheim Peninsula, $79^{\circ} 34^{\prime} \mathrm{N} 84^{\circ} 44^{\prime} \mathrm{W}$, Edlund \& RoncatoSpencer 262 (CAN 535348, 533280); Fosheim Peninsula, $79^{\circ} 58^{\prime} \mathrm{N} 84^{\circ} 26^{\prime} \mathrm{W}$, Edlund \& Roncato-Spencer 275 (CAN);

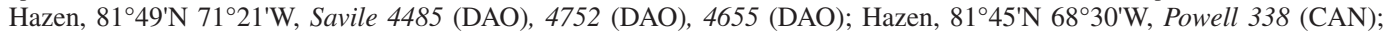
Hazen, $82^{\circ} \mathrm{N} 70^{\circ} \mathrm{W}$, Soper 8273 (CAN); Makinsen Inlet, $76^{\circ} 41^{\prime} \mathrm{N} 81^{\circ} 37^{\prime} \mathrm{W}$, Blake 7 (DAO); Mount Pullen, $82^{\circ} 25^{\prime} \mathrm{N}$

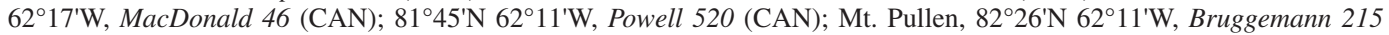

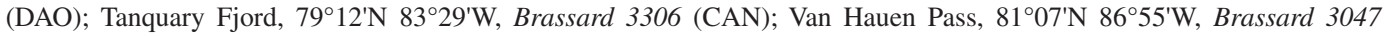
(CAN); Vesle Fjord, $79^{\circ} 12^{\prime} \mathrm{N} 83^{\circ} 29^{\prime} \mathrm{W}$, Edlund \& Roncato-Spencer 282 (CAN). Somerset Island: $72^{\circ} 56^{\prime} \mathrm{N} 94^{\circ} 57^{\prime} \mathrm{W}, Z^{\circ}$ oltai 741044 (DAO).

NORTHWEST TERRITORIES. Melville Island: $74^{\circ} 58^{\prime} \mathrm{N} 115^{\circ} 02^{\prime} \mathrm{W}$, Parker $44 f$ (DAO); Bailey Point, $74^{\circ} 58^{\prime} \mathrm{N}, 115^{\circ} 02^{\prime} \mathrm{W}$,

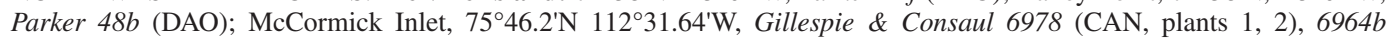
(CAN). Prince Patrick Island: Green Bay, 76³3.67'N 118 53.09'W, Gillespie \& Consaul 6870 (CAN, plant 1); Intrepid Inlet, $75^{\circ} 46.9^{\prime} \mathrm{N} 112^{\circ} 22.09^{\prime} \mathrm{W}$, Gillespie \& Consaul 6877 (CAN, plant 1); Mould Bay, 76 $21.5^{\prime} \mathrm{N} 119^{\circ} 30.5^{\prime} \mathrm{W}$, Gillespie \& Consaul 6881 (CAN, plants 1-6); Mould Bay, 76 $14^{\prime} \mathrm{N} 118^{\circ} 57^{\prime} \mathrm{W}$, Gillespie \& Consaul 6825 (CAN, plants 1-3); Mould Bay, $76^{\circ} 14.5^{\prime} \mathrm{N} 119^{\circ} 21^{\prime} \mathrm{W}$, Gillespie \& Consaul 6807 (CAN, plants 1-5). Victoria Island: Ulusartok Peninsula, $70^{\circ} 44^{\prime} \mathrm{N}$ $117^{\circ} 44^{\prime} \mathrm{W}$, Edlund 875 (CAN).

ALASKA. Kenai Peninsula. 6049'N 149³3'W, Calder 6511, 6249, 6107 (DAO).

BRITISH COLUMBIA. Haines Junction, Calder \& Kukkonen 28151 (DAO); Haines, Taylor et al. 1204 (DAO).

Mixed collections - Saxifraga tenuis and Saxifraga nivalis on same sheet

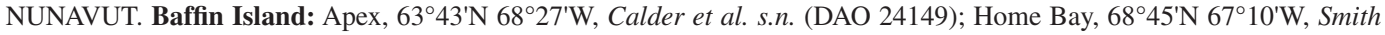
VP-53-61 (CAN). Ellesmere Island: Tanquary Fjord, $79^{\circ} 12^{\prime} \mathrm{N} 83^{\circ} 29^{\prime} \mathrm{W}$, Brassard $3317(\mathrm{CAN})$; Hazen, $81^{\circ} 49^{\prime} \mathrm{N} 71^{\circ} 21^{\prime} \mathrm{W}$, Savile 4562 (DAO).

NORTHWEST TERRITORIES. Victoria Island: near Holman, $70^{\circ} 43^{\prime} \mathrm{N} 117^{\circ} 43^{\prime} \mathrm{W}$, Edlund 719 (CAN). Prince Patrick Island: Mould Bay, $76^{\circ} 12^{\prime} \mathrm{N} 119^{\circ} 25^{\prime} \mathrm{W}$, MacDonald 150 (CAN, S. tenuis: 1, 3, 4, 7, 8, 9; S. nivalis: 2, 5, 6, 10). 